\title{
Enzymatic destruction of protopectin in vegetable raw materials to increase its structuring ability in ice cream
}

\author{
Viktoria Sapiga, Galina Polischuk, Natalia Breus, Tetiana Osmak
}

\author{
National University of Food Technologies, Kyiv, Ukraine
}

\section{Keywords:}

Ice-cream.

Vegetable

Pectin

Pectinase

Hydrolysis

Viscosity

\section{Article history:}

Received

14.06.2020

Received in revised

form 01.12.2020

Accepted

30.06.2021

\section{Corresponding author:}

Tetiana Osmak

E-mail:

osmaktg@ukr.net
DOI:

$10.24263 / 2304-$

974X-2021-10-2-9

\section{Abstract}

Introduction. The expediency of protopectin enzymatic hydrolysis of vegetable raw materials as a functional-technological semi-finished product for ice cream production is proved.

Materials and methods. Rheological characteristics of fermented and unfermented vegetable purées, as well as milkvegetable mixtures were studied. The efficiency of enzymolysis was determined by the calcium pectate method, the effective viscosity by rotational viscosimetry, and the active acidity potentiometrically.

Results and discussion. The purpose of the work is to study the influence of the degree of protopectin enzymatic hydrolysis of vegetable purées of different types on their structuring ability in the composition of ice cream.

The advantage of protopectin enzymatic hydrolysis in vegetable purées, compared with acid hydrolysis, is to increase the yield of soluble pectin by $8-12 \%$ at lower energy consumption. Parameters of the process of protopectin enzymolysis by the degree of protopectin hydrolysis (not less than 90\%): for different types of vegetable raw materials with a pectin content of 0.22 to $2.56 \%$ were optimized. For carrots and beets, the need for the enzyme is highest $(0.1-0.2 \%)$ with a prolonged duration of the fermentation process (from 120-180 minutes to 240 minutes). For zucchini, broccoli and tomatoes, the duration of process is reduced to 60-120 minutes while reducing the dose of the enzyme - up to $0.05-0.10 \%$. At the prolongation of the enzymolysis process due to excessive hydrolysis of pectin substances, the effective viscosity of vegetable purees decreases somewhat. The thixotropic capacity of these systems is also reduced. Partial loss of functional and technological properties of vegetable raw materials due to excessive hydrolysis of pectin substances has a negative impact on the rheological characteristics of milk-vegerable mixtures for the ice cream production. Vegetable raw materials increase the effective viscosity of milk-vegetable mixtures for ice cream production under the recommended fermentation conditions, which can be explained by the formation of structuring complexes between polysaccharides and milk proteins.

Conclusions. Protopectin of enzymatic hydrolysis is more efficient than acid hydrolysis and depends on the physicochemical characteristics of vegetables. Fermented vegetable purées are structuring systems and show thixotropy in the composition of mixtures for the production of ice cream. 


\section{- Food Technology -}

\section{Introduction}

In dispersed food systems, pectins as protective colloids have a stabilizing and emulsifying ability, form a creamy consistency, increase whipping and control syneresis (Voragen et al., 2009), which is important for the formation of ice cream quality indicators. Highly purified pectin preparations are usually used in ice cream. At the same time, significant theoretical and practical interest is pectin-containing raw materials, the technological properties of which are activated by hydrolytic conversion of protopectin to the active state (Polishchuk et al., 2013). Exactly soluble pectin that has the ability to form gels in an acidic environment and in the presence of sugar (Ivashhenko, 2015). This property confirms the feasibility of using pectin to form and stabilize the structure of ice cream with fruits, berries, and vegetables.

Pectin-containing vegetable raw materials have not yet been widely used in technologies of different types of ice cream, due to the specific organoleptic properties of certain types of vegetable raw materials and its relatively low structural ability, which depends on the conditions of pre-processing (Torres and Canet, 2001; Pavlyuk et al., 2018; Syed et al., 2018; Hassan and Barakat, 2018).

Activation of pectin-containing raw materials by increasing the content of soluble pectin as a product of protopectin hydrolysis increases its ability to bind water and structure food systems. Thus, the content of soluble pectin in fruit and vegetable purees can reach 1.5-2.0\% (Yovbak et al., 2013; Müller-Maatsch et al., 2016).

But traditional methods of acid and alkaline activation of pectin-containing fruit and vegetable raw materials are energy-intensive and characterized by too harsh processing conditions, which leads to a partial loss of its structural ability (Canteri et al., 2012; Deynychenko et al., 2016).

Instead, the hydrolytic action of pectolytic enzymes, which is aimed at the connection of protopectin with cellulose and hemicellulose, allows to more effectively carry out its transition to soluble form with maximum preservation of native properties (Zapata A. D et al., 2017). The kinetics and dynamics of the enzymolysis process can be easily regulated (Abbès et al., 2011), which is also a significant advantage of this method of destruction of protopectin.

Pectinase is effectively used to increase juice yield and improve filtration during juice extraction, as well as to clarify juices and wine materials. The enzyme preparation also allows to obtain fruit purees and jellies (Zapata A. D. et al., 2009; Habibrahmanova et al., 2018). At the same time, protopectin enzymolysis should be carried out only to a technologically appropriate level, which requires additional research.

The main way to inactivate enzyme preparations is high temperature. But the thermal effect on fermented vegetable raw materials should be short-lived for maximum preservation of thermally unstable biologically active compounds (vitamin C, B vitamins, etc.) (Gonzalez and Rosso, 2011). Vegetables that are promising for ice cream production have different pulp strength, different content, and properties of pectin substances (Voragen et al., 2009), which requires further detailed study in each case.

Thus, the possible study of enzymatic processing of vegetable raw materials of different types in order to purposefully influence its structuring ability in the composition of ice cream is an urgent scientific task.

The purpose of the work is to study the effect of protopectin enzymatic hydrolysis in vegetable purées on their structuring ability in ice cream.

The following research tasks were formed:

- Choose the most promising types of vegetable raw materials for ice cream production; 


\section{— Food Technology}

- To conduct a comparative analysis of the acid and enzymatic hydrolysis effectiveness of vegetable raw materials by the degree of protopectin destruction;

- To establish the optimal modes of protopectin enzymatic hydrolysis in vegetable raw materials;

- To investigate the influence of the hydrolysis degree of the protopectin on the structuring ability of vegetable purees and milk-vegetable mixtures for ice cream production.

\section{Materials and methods}

\section{Materials}

The most promising and little-studied vegetables for use in ice cream were selected for the research: table beets, zucchini, broccoli and tomatoes. Carrots were studied as a traditional vegetable for ice cream production with a maximum content of pectin (Hassan and Barakat, 2018).

It was selected the most affordable and relatively cheap varieties of vegetables grown in Ukraine: table beets "Delicatessen", broccoli "Jaguar", carrots "Queen of Autumn", tomatoes "Asterix F1", zucchini "Cavili".

As a hydrolyzing preparation enzyme Pectolad (SE "Enzyme", Ukraine) with a pectolytic activity of at least 30 units/g. Pectolad belongs to pectinases. The preparation contains a complex of pectolytic enzymes (endo- $\alpha 1,4-$ polygaclacturonase, exo- $\alpha 1,4-$ polygalacturonase) and catalyzes the hydrolysis of internal 1-4-linked $\alpha$-D-galacturonoside bonds in the main chain of polygalacturonates and pectin substrates with low degree of esterification. The enzyme preparation is obtained by targeted deep fermentation of the strain Aspergillus foetidus. The recommended dosage of pectolad, depending on the type of raw material and technological process, is on average $50-100 \mathrm{~g} / 100$ liters. The operating temperature range of the enzyme at an acidity of $\mathrm{pH} 2.0-5.2$ is $25-55^{\circ} \mathrm{C}$.

\section{Methods}

Quantitative pectin content was determined by calcium pectate method (Podkorytova and Kadnikova, 2009).

The viscosity characteristics of fermented and unfermented vegetable purées and milkvegetables blends were determined on a rotary viscometer with a measuring system cylindercylinder by removing the curves of deformation kinetics (flow). The measurements were performed at a temperature of $20{ }^{\circ} \mathrm{C}$. Shear stress measurements $\tau(\mathrm{Pa})$ were performed at twelve values of the shear rate gradient $\mathrm{D}$ in the range from 3 to $1312.2 \mathrm{~s}^{-1}$ at forward and reverse (Bass O et al., 2017).

The active acidity was measured potentiometrically (Tomovska et al., 2016).

Optimization of the process of vegetable protopectin enzymatic hydrolysis was performed using the mathematical package MathCad 15 (Breus et al., 2019; Dayong et al., 2020). The regression equations were obtained in order to identify the optimal modes of fermentation of vegetable purées of different species to ensure protopectin hydrolysis at least $90 \%$ of its total amount. 


\section{- Food Technology -}

\section{Organization of the study}

To obtain homogeneous purée, vegetables were washed, cleaned, cut into pieces measuring $20 \times 20 \mathrm{~mm}$, blanched until soft for no longer than 5 minutes, ground at a temperature of $50-55^{\circ} \mathrm{C}$ to a homogeneous mass using a homogenizer with cutting knives at a speed of 1000 minutes -1 for 3 minutes to a particle size not larger than 1-2 mm.

Ice cream mixtures were pasteurized $\left(85 \pm 2{ }^{\circ} \mathrm{C}, 3 \mathrm{~min}\right)$, homogenized $(12 \pm 1 \mathrm{MPa})$, cooled, vegetable puree was added, mixed and incubated $\left(4 \pm 2{ }^{\circ} \mathrm{C}, 2 \mathrm{~h}\right)$. The mixtures were heated to $20^{\circ} \mathrm{C}$ before measuring the effective viscosity. The content of vegetable purée was $35 \%$, sugar $-15 \%$, fat $-3.5 \%$, dry skimmed milk residue $-10 \%$.

At the first stage of the study to compare the effectiveness of different methods of destruction of protopectin in vegetable purées studied the yield of soluble pectin in the case of acid and enzymatic hydrolysis.

Acid hydrolysis was performed at the average values of the recommended modes temperature $90^{\circ} \mathrm{C}$, duration $45 \mathrm{~min}$, active acidity $\mathrm{pH}=2.0$ (Canteri et al., 2012). Citric acid was used to regulate the acidity of vegetable purees.

Fermentolysis of vegetable purées was carried out at the average values of the technological modes recommended by the manufacturers: mass fraction of enzyme $-0.1 \%$, temperature $40^{\circ} \mathrm{C}$, processing time $-2 \mathrm{~h}$, active acidity -4.0 units. $\mathrm{pH}$. After fermentation, the pectinase was inactivated by heating the samples to $90^{\circ} \mathrm{C}$ without exposure. The redistribution of pectin substances was studied in samples cooled to a temperature of $20^{\circ} \mathrm{C}$. The content of pectin substances (PS), protopectin (PP) and soluble pectin (SP) was determined in fresh and processed vegetable purée.

At the second stage of the study to optimize the process of protopectin enzymolysis of different vegetables to the prepared samples of purée with a given acidity $\mathrm{pH}=4.0$ was added enzyme in an amount of from 0.05 to $0.25 \%$ in increments of $0.05 \%$ - from 60 to 240 minutes. Soluble pectin content and effective viscosity of vegetable purée samples were determined.

At the third stage, the effect of soluble pectin content in vegetable purées on their structuring ability, including in the composition of mixtures for ice cream production, was studied.

\section{Results and discussion}

\section{Comparative analysis of the different methods' effectiveness of protopectin destruction in vegetable purées}

The most promising and lesser known vegetables for use in ice cream were selected for the study: table beets, zucchini, broccoli and tomatoes. Carrots were studied as a traditional vegetable for ice cream production with a maximum content of pectin. The average chemical composition of vegetables in descending order of pectin content is given in Table 1 (Golub et al., 2013; Velichko et al., 2018; Machulkina et al., 2014; Sagar et al., 2018).

According to Table 1, it should be noted that the mass fraction of pectin in selected vegetables varies from $0.03-0.23 \%$ to $1.57-2.93 \%$, depending on the variety. Also, these vegetables are very strong pulp, and can perform various functions in the composition of ice cream, including coloring this product due to the content of $\beta$-carotene, anthocyanins, chlorophyll. 
Chemical composition of vegetables

\begin{tabular}{|l|c|c|c|c|c|c|c|}
\hline \multirow{2}{*}{$\begin{array}{c}\text { Kind of } \\
\text { vegetables }\end{array}$} & \multicolumn{7}{|c|}{ Contents of } \\
\cline { 2 - 8 } & water, \% & $\begin{array}{c}\text { dry } \\
\text { matter, } \\
\text { \% }\end{array}$ & ash, \% & $\begin{array}{c}\text { organic } \\
\text { acids, \% }\end{array}$ & $\begin{array}{c}\text { pectin } \\
\text { substances, \% }\end{array}$ & $\begin{array}{c}\text { proteins, } \\
\text { \% }\end{array}$ & $\begin{array}{c}\text { vitamin } \\
\text { C, } \\
\text { mg\% }\end{array}$ \\
\hline $\begin{array}{l}\text { Table } \\
\text { carrot }\end{array}$ & $86-8.8$ & $13-14$ & 0.6 & 0.2 & $1.57-2.93$ & $1.0-2.2$ & 5 \\
\hline $\begin{array}{l}\text { Table } \\
\text { beet }\end{array}$ & $86.0-87.0$ & 18.6 & 1.35 & 0.08 & $1.15-1.5$ & 1.5 & 17.92 \\
\hline Zucchini & $93.0-96.0$ & $4.6-4.8$ & 0.49 & $0.05-0.1$ & $1.0-1.4$ & $0.4-0.6$ & 17 \\
\hline Broccoli & $88.68-91.46$ & $10.5-13.1$ & $0.76-0.8$ & 0.8 & $0.76-0.87$ & 2.74 & 89.2 \\
\hline Tomatoes & $88.0-92.0$ & $4.0-6.0$ & $5.6-5.8$ & $0.3-0.7$ & $0.03-0.23$ & $0.6-1.6$ & $20-40$ \\
\hline
\end{tabular}

Available and relatively cheap varieties of vegetables grown in Ukraine were selected for the study: table beets "Delicatessen", broccoli "Jaguar", table carrots "Queen of Autumn", tomatoes "Asterix F1", zucchini "Cavili".

The nature of the change in the content of PS, PP and SP in vegetable purees under stable conditions of the hydrolysis process is given in Table 2.

According to Table 2, for all vegetables, the increase in the content of PS was accompanied by a decrease in the content of PP. The maximum yield of SP, compared with its content in fresh purees, was observed in the case of enzymolysis - 5.0-5.3 times for beet and carrot, 5.6-5.9 times for zucchini and broccoli and 6.7 times for tomatoes. This figure was slightly lower in the case of acid hydrolysis with an increase in SP yield - 4.6-4.8 times for beets and carrots, 5-5.4 times for zucchini and broccoli and 6 times for tomatoes. Thus, the largest changes in the SP content were found for vegetables with low pulp strength (zucchini, broccoli, tomatoes), and slightly smaller - for vegetables with a stronger structure (carrots and beets). This is probably due to the fact that stronger fibers of carrots and beets, even in a mechanically destroyed state, partially shielded the access of hydrolytic agents to protopectin. It should also be noted that the total amount of pectin after hydrolysis is slightly reduced, which indicates the formation of intermediate products of their destruction.

The role of pre-blanching of vegetables was quite noticeable, during which the content of soluble pectin increased on average three times, which correlates with the data on blanching of pectin-containing fruits (Levi et al., 2006). This confirms the need for prethermal softening of vegetables not only to facilitate their grinding into homogeneous purees, but also to ensure the gradual and more efficient hydrolysis of protopectin. The advantage of enzymatic hydrolysis over acid hydrolysis of pectin substances is obvious not only at higher SP yield, but also due to lower heat consumption $\left(40^{\circ} \mathrm{C}\right.$ vs $\left.90{ }^{\circ} \mathrm{C}\right)$. Enzymolysis occurs at a relatively moderate acidity of vegetable purees $(\mathrm{pH}=4.0)$, which is more acceptable for the production of ice cream than acid hydrolysis at $\mathrm{pH}=2.0-2.5$. Thus, enzymatic hydrolysis allows to increase the yield of soluble pectin by an average of $-12 \%$ at lower energy consumption, maximum preservation of biologically active compounds of vegetable raw materials, better organoleptic and physico-chemical characteristics of vegetable purees for further use in ice cream.

The advantages of using enzymatic hydrolysis over acid hydrolysis were also noted by Liew S.Q. etc. according to the results of comparative analysis of both methods on the example of passion fruit peel processing (Liew et al., 2016). 
Distribution of pectin substances in vegetable purees $(P \geq 0,95, n=3)$

\begin{tabular}{|c|c|c|c|}
\hline \multirow[t]{2}{*}{ Model samples } & \multicolumn{3}{|c|}{$\begin{array}{c}\text { Mass fraction of pectin substances, } \\
\mathrm{g} / 100 \mathrm{~g}\end{array}$} \\
\hline & PS & PP & SP \\
\hline \multicolumn{4}{|c|}{ Table carrot } \\
\hline Fresh puree & $0,41 \pm 0,01$ & $2,15 \pm 0,09$ & $2,56 \pm 0,11$ \\
\hline Puree after blanching & $1,25 \pm 0,04$ & $1,30 \pm 0,04$ & $2,55 \pm 0,10$ \\
\hline Puree after blanching and acid hydrolysis & $1,98 \pm 0,05$ & $0,55 \pm 0,02$ & $2,53 \pm 0,09$ \\
\hline Puree after blanching and enzymolysis & $2,17 \pm 0,07$ & $0,36 \pm 0,01$ & $2,53 \pm 0,09$ \\
\hline \multicolumn{4}{|c|}{ Table beet } \\
\hline Fresh puree & $0,21 \pm 0,01$ & $1,02 \pm 0,05$ & $1,23 \pm 0,04$ \\
\hline Puree after blanching & $0,61 \pm 0,02$ & $0,62 \pm 0,02$ & $1,23 \pm 0,03$ \\
\hline Puree after blanching and acid hydrolysis & $0,96 \pm 0,03$ & $0,26 \pm 0,01$ & $1,22 \pm 0,02$ \\
\hline Puree after blanching and enzymolysis & $1,06 \pm 0,06$ & $0,16 \pm 0,01$ & $1,22 \pm 0,01$ \\
\hline \multicolumn{4}{|c|}{ Zucchini } \\
\hline Fresh puree & $0,20 \pm 0,01$ & $0,98 \pm 0,02$ & $1,18 \pm 0,03$ \\
\hline Puree after blanching & $0,62 \pm 0,03$ & $0,55 \pm 0,02$ & $1,17 \pm 0,04$ \\
\hline Puree after blanching and acid hydrolysis & $1,00 \pm 0,03$ & $0,17 \pm 0,01$ & $1,17 \pm 0,02$ \\
\hline Puree after blanching and enzymolysis & $1,12 \pm 0,04$ & $0,05 \pm 0,002$ & $1,17 \pm-, 02$ \\
\hline \multicolumn{4}{|c|}{ Broccoli } \\
\hline Fresh puree & $0,14 \pm 0,01$ & $0,73 \pm 0,03$ & $0,87 \pm 0,02$ \\
\hline Puree after blanching & $0,45 \pm 0,02$ & $0,41 \pm 0,02$ & $0,86 \pm 0,02$ \\
\hline Puree after blanching and acid hydrolysis & $0,76 \pm 0,02$ & $0,09 \pm 0,01$ & $0,85 \pm-0,03$ \\
\hline Puree after blanching and enzymolysis & $0,82 \pm 0,03$ & $0,03 \pm 0,01$ & $0,85 \pm 0,02$ \\
\hline \multicolumn{4}{|c|}{ Tomatoes } \\
\hline Fresh puree & $0,03 \pm 0,001$ & $0,19 \pm 0,01$ & $0,22 \pm 0,01$ \\
\hline Puree after blanching & $0,10 \pm 0,005$ & $0,11 \pm 0,01$ & $0,21 \pm 0,01$ \\
\hline Puree after blanching and acid hydrolysis & $0,18 \pm 0,01$ & $0,03 \pm 0,002$ & $0,21 \pm 0,01$ \\
\hline Puree after blanching and enzymolysis & $0,20 \pm 0,01$ & $0,01 \pm 0,001$ & $0,21 \pm 0,01$ \\
\hline
\end{tabular}

\section{Determination of optimal parameters of protopectin enzymatic hydrolysis process in vegetable purées}

To determine the efficiency of enzymatic hydrolysis of vegetable protopectin by variable parameters of this process, regression equations were obtained in the form of multidimensional polynomials of the second degree. The equations describe the dependence of soluble pectin content $(\%)$ on the amount of enzyme preparation $(0.05-0.25 \%)$ and the duration of biotechnological treatment (60-240 $\mathrm{min}$ ) of vegetable purées obtained from the blanched pulp.

In coded form, the regression equations have the following form: 


$$
\begin{aligned}
& \mathrm{Z} 1(\mathrm{x}, \mathrm{y}):=0.60534+8.77724 \mathrm{x}-24.90331 \mathrm{x}^{2}+0.01508 \mathrm{y}-0.00004 \mathrm{y}^{2}-0.01172 \mathrm{xy} \\
& \mathrm{Z} 2(\mathrm{x}, \mathrm{y}):=0.44088+1.89409 \mathrm{x}-4.06224 \mathrm{x}^{2}+0.00648 \mathrm{y}-0.00002 \mathrm{y}^{2}-0.00354 \mathrm{xy} \\
& \mathrm{Z} 3(\mathrm{x}, \mathrm{y}):=0.44165+2.82174 \mathrm{x}-7.32555 \mathrm{x}^{2}+0.00779 \mathrm{y}-0.00002 \mathrm{y}^{2}-0.0094 \mathrm{xy} \\
& \mathrm{Z} 4(\mathrm{x}, \mathrm{y}):=0.49817+2.06334 \mathrm{x}-5.35853 \mathrm{x}^{2}+0.00681 \mathrm{y}-0.00002 \mathrm{y}^{2}-0.00783 \mathrm{xy} \\
& \mathrm{Z} 5(\mathrm{x}, \mathrm{y}):=0.10596+0.1903 \mathrm{x}-0.82497 \mathrm{x}^{2}+0.0014 \mathrm{y}-0.0000049 \mathrm{y}^{2}-0.00127 \mathrm{xy}
\end{aligned}
$$

where: Z1, Z2, Z3, Z4, and Z5 - a mass fraction of soluble pectin in mashed carrots, beets, zucchini, broccoli, and tomatoes, $\% ; \mathrm{X}$ is the mass fraction of the enzyme, $\%$; $\mathrm{Y}$ is the duration of enzymolysis, $\min$

The accuracy of the approximation is $\delta \mathrm{Z}= \pm 0.01 \%$.

To ensure the degree of protopectin hydrolysis not less than $90 \%$, the optimal parameters for vegetable purees with a pectin content of 0.22 to $2.56 \%$ are as follows:

- for carrots and beets with an enzyme content of $0.1-0.15 \%$, the duration of enzymolysis - 180-240 minutes, with a content of $0.2 \%-120-180$ minutes;

- for zucchini, broccoli and tomatoes for doses of the enzyme - up to $0.05-0.10 \%$, the duration of enzymolysis is 60-120 minutes.

The results of the study show a significant difference between the optimal parameters of the fermentation process for two groups of vegetables, which differ in the content of protopectin and the strength of plant cell walls (Gonzalez and Barrett, 2010; Sagar et al., 2018). Therefore, it can be argued that the physicochemical characteristics of the selected vegetable raw materials significantly affect the technologically appropriate parameters of the pectin substances fermentation process.

For all vegetables it should be noted that in excess of the optimal dose of the enzyme and the duration of enzymolysis, there is a slight decrease in the content of SP. This is probably due to the partial depolymerization of pectin compounds, which are not identified by the calcium pectate method (Podkorytova and Kadnikova, 2009). Partial destruction of pectin compounds can lead to deterioration of their structural ability, which must be experimentally verified.

\section{Structuring ability study of the vegetables purées of different degrees of processing}

At the next stage of the study on the example of carrot purée, which contains the most pectin, determined the effective viscosity:

- Fresh purée (control);

- Purée fermented at a content of $0.1 \%$ enzyme for 180 minutes (sample 1);

- Purée fermented at a content of $0.25 \%$ of the enzyme for 240 min (sample 2).

The effective viscosity of the practically intact structure $\left(\eta_{0}\right)$ at the shear rate $\gamma=3 \mathrm{~s}^{-1}$ in the direct course of measurement, the effective viscosity of the extremely destroyed structure $\left(\eta_{\mathrm{m}}\right)$ at the shear rate $\gamma=1312,2 \mathrm{~s}^{-1}$ and the effective viscosity of the reduced structure $\left(\eta_{\mathrm{n}}\right)$ at the speed $\gamma=3 \mathrm{~s}^{-1}$ shear at the reverse of the measurement is shown in Figure 1. 


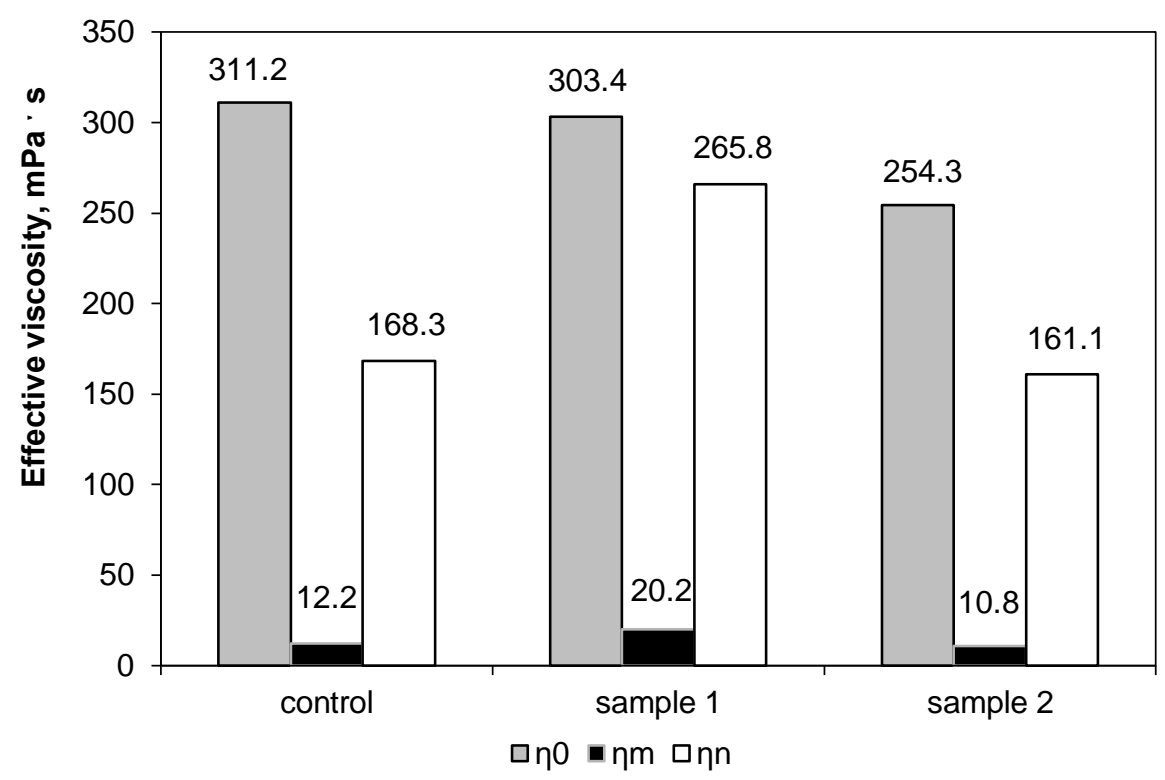

Figure 1. Effective viscosity of fresh and fermented vegetable purée samples at different stages of measurement using a rotary viscometer

Figure 1 confirms the previous assumption regarding the possible reduction of the structural ability of vegetable puree in the case of excessive hydrolysis of pectin substances. It is also interesting that the protopectin hydrolysis under optimal modes of this process even slightly reduces the initial effective viscosity of carrot puree $(311.2 \mathrm{mPa} \cdot \mathrm{s}$ vs $303.4 \mathrm{mPa} \cdot \mathrm{s})$, but significantly increases its thixotropic capacity. The difference between the values of the effective viscosity of the samples fermented under rational regimes (sample 1) and their excess (sample 2) was $104,7 \mathrm{mPa} \cdot \mathrm{s}$ with a decrease in the shear rate to $\gamma=3 \mathrm{~s}^{-1}$ in the reverse course of the measurement.

According to the authors, the ticotropic ability of pectin-containing raw materials in ice cream mixes that is extremely important. Too much thickening of mixtures in ice cream technology is undesirable, as their foaming ability may be reduced (Milliatti and Lannes, 2018).

Initial viscosity is not the main rheological characteristic of mixtures, as their ability to rapidly destroy the structure during freezing of mixtures and to quickly recover over time under static portions of soft ice cream portions after molding before hardening is more significant.

Therefore, in the last stage of the experiment, the effective viscosity of vegetable ice cream mixtures with the content of unfermented and fermented under optimal modes of carrot puree in the amount of $35 \%$ was investigated. The effective viscosity of mixtures with vegetable puree, in comparison with the control mixture without vegetables, is shown in Figure 2. 

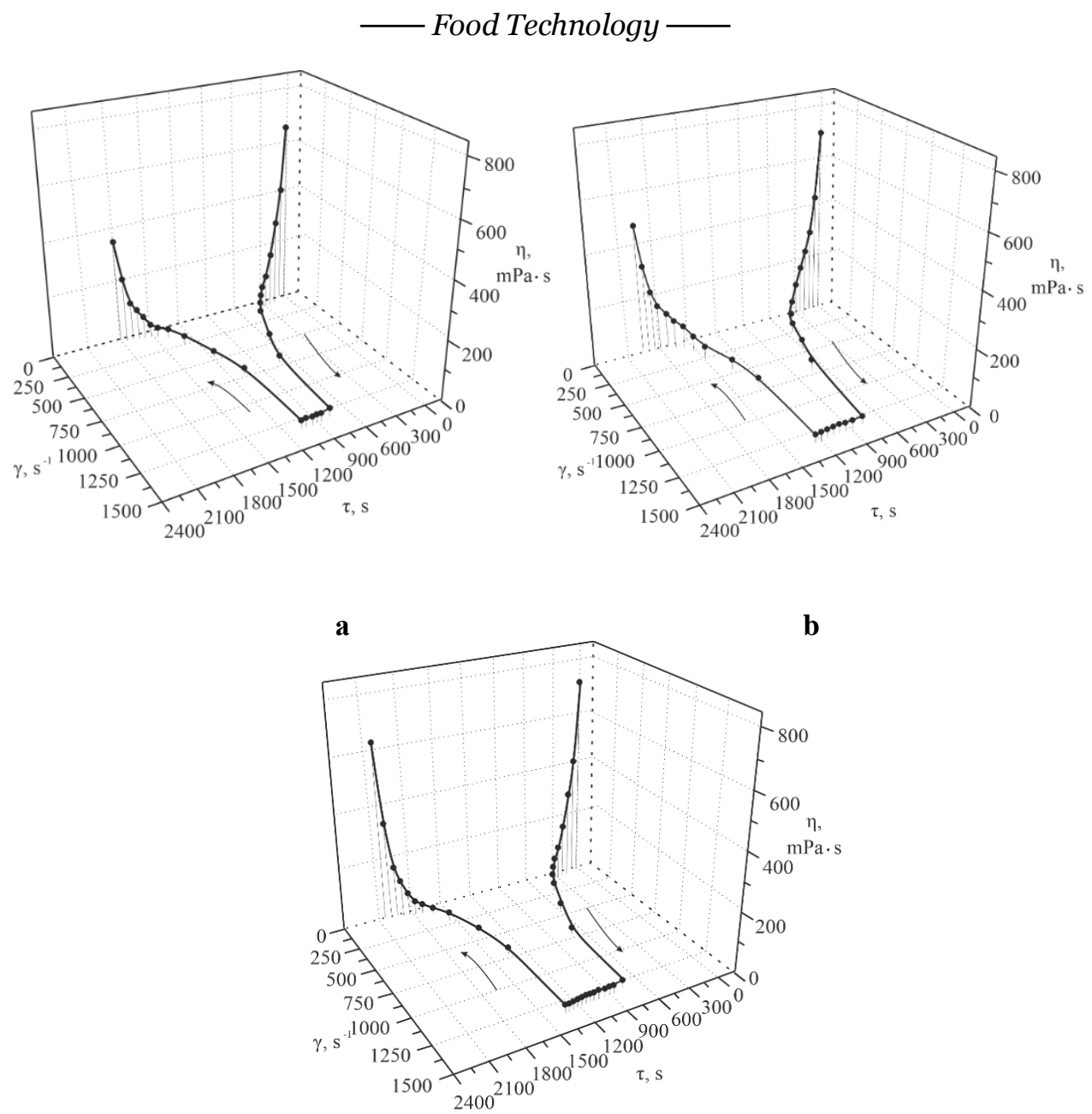

c

Figure 2. Effective viscosity of milk mixtures with a variable shear rate gradient: a - control; $b$ - milk-vegetable mixture with unfermented vegetable purée; $\mathbf{c}$ - milk-vegetable mixture with fermented vegetable purée

The results of the last stage of the study confirmed the increased thixotropic capacity of pectin-containing fermented raw materials compared to unfermented in the composition of milk mixtures .

Also, important is the ability of the mixture with fermented puree to a significant and relatively rapid destruction of the structure over time, with its subsequent recovery by reducing the destructive force. Aeration of low-viscosity ice cream mixes is greatly facilitated during freezing.

It is known that excessive thickening of ice cream mixes is undesirable, as it may reduce their foaming ability (Milliatti and Lannes, 2018). The positive effect of the presence of 


\section{Food Technology}

pectic substances in milk formulas is also obvious, which allows to obtain structured systems within the recommended limits of effective viscosity (Liew et al., 2016; Akalın et al., 2008).

It should be noted the increase in time during which the shear rate $\gamma=1312 \mathrm{~s}^{-1}$ obtained the lowest viscosity of the extremely destroyed structure for a mixture with fermented vegetable purée, compared with the sample with unfermented purée and the control sample. The observed effect indicates the presence of more low-energy coagulationtype bonds and surface contacts between the particles of enzymatically treated plant material.

A fundamentally new result of the study is the significant influence of fermented vegetable purée on the rheological characteristics of milk-vegetable mixtures. The high content of soluble pectin and the formation of complexes "protein-polysaccharide" mixtures with fermented puree show high structuring ability and thixotropic properties. Spontaneous restoration of the structure of milk-vegetable mixtures by reducing the shear rate will increase the stabilization of the structure of the formed portions of ice cream in static conditions.

The prospect of further research is to study the degree of preservation in vegetable hydrolyzed purees of biologically valuable compounds (vitamins, pigments, phenolic compounds, etc.) and the development of scientifically sound recipes for vegetable and milk ice cream.

\section{Conclusions}

1. Enzymatic hydrolysis of protopectin in vegetable purees with a pectin content of 0.22 to $2.56 \%$ is more efficient than acid hydrolysis and allows to increase the yield of soluble pectin by $8-12 \%$ at lower energy consumption.

2. To ensure the hydrolysis of at least $90 \%$ of protopectin, it is necessary to use from 0.05 to $0.2 \%$ of the enzyme preparation for $60-120$ minutes to 240 minutes, depending on the type of vegetable and the strength of its tissues.

3. The use of fermented vegetable purées in milk formulas allows obtaining structured systems with the recommended values of effective viscosity and pronounced thixotropic ability.

4. Excessive enzymolysis reduces the structuring ability of vegetable purees, which negatively affects the rheological characteristics of milk-vegetable mixtures for ice cream production.

\section{References}

Abbès F., Bouaziz M. A., Blecker C., et al. (2011), Date syrup: effect of hydrolytic enzymes (pectinase/cellulase) on physico-chemical characteristics, sensory and functional properties, LWT-Food science and Technology, 44(8), pp. 1827-1834, DOI: 10.1016/j.lwt.2011.03.020.

Akalın A. S., Karagözlü C., Ünal G. (2008), Rheological properties of reduced-fat and low-fat ice cream containing whey protein isolate and inulin, European Food Research and Technology, 227(3), pp. 889-895, DOI: 10.1007/s00217-007-0800-z.

Bass O., Polischuk G., Goncharuk E. (2017), Investigation of viscous characteristics of ice cream mixtures with starch syrup. Ukrainian Food Journal, 6(2), pp. 269-277, DOI: 10.24263/2304- 974X-2017-6-2-8. 
Breus N., Hrybkov S., Polischuk G., et al. (2019), Development of mathematical apparatus of the expert system for modelling ice cream recipes with specified quality parameters, Science and Innovation, 15(5), pp. 57-66, DOI: 10.15407/scine15.05.057.

Canteri M. H., Moreno L., Wosiacki G., et al. (2012), Pectina: da matéria-prima ao produto final, Polímeros, 22(2), pp. 149-157, DOI: 10.1590/S0104-14282012005000024.

Deynychenko G., Gnitsevych V., Yudina T., et al. (2016), The study of technological parameters of pectin containing raw material processing in the vegetable-milk forcemeats technology, EUREKA: Life Sciences, (4), pp. 29-36, DOI: 10.21303/2504-5695.2016.00189.

Golub O. V., Gabinskij A. V., Kovalevskaja I. N. (2013), Issledovanie prigodnosti k pererabotke kabachkov, proizrastajushhih v Kemerovskoj oblasti, Tehnika i tehnologija pishevyh proizvodstv, 4(31), pp. 9-13.

Gonzalez M. E., Barrett D. M. (2010), Thermal, high pressure, and electric field processing effects on plant cell membrane integrity and relevance to fruit and vegetable quality, Journal of Food Science, 75(7), pp. R121-R130, DOI: 10.1111/j.17503841.2010.01763.x.

Gonzalez S. L., Rosso N. D. (2011), Determination of pectin methylesterase activity in commercial pectinases and study of the inactivation kinetics through two potentiometric procedures, Food Science and Technology, 31, pp. 412-417, DOI: 10.1590/S010120612011000200020.

Habibrahmanova V. R., Sysoeva M. A., Habibullina L. R., et al. (2018), Podbor uslovij ekstrakcii pektina iz yablochnyh vyzhimok s primeneniem fermenta activnogo gidroliza, Vestnik tehnologicheskogo universiteta, 21(1), pp. 190-192.

Hassan M. F., Barakat H. (2018), Effect of carrot and pumpkin pulps adding on chemical, rheological, nutritional and organoleptic properties of ice cream, Food and Nutrition Sciences, 9(8), pp. 969-982, DOI: 10.4236/fns.2018.98071.

Ivashhenko M. V. (2015), Faktory, vlijajushhie na fermentoliz pektinsoderzhashhego rastitel'nogo syr'ja, Nizkotemperaturnye i pishhevye tehnologii v XXI veke, 2, pp. 305-308, DOI: 10.36718/1819-4036-2021-6-176-184.

Levi A., Ben-Schalom N., Plat D., et al. (2006), Effect of Blanching and Drying on Pectin Constitutents and Related Characteristics of Dehydrated Peaches, Journal of Food Science, 53(4), pp. 1187-1190, DOI: 10.1111/j.1365-2621.1988.tb13558.x.

Liew S. Q., Chin N. L., Yusof Y. A. et al. (2016), Comparison of acidic and enzymatic pectin extraction from passion fruit peels and its gel properties, Journal of Food Process Engineering, 39(5), pp. 501-511, DOI: 10.1111/jfpe.12243.

Machulkina V. A., Sannikova T. A., Avdeev Ju. I. (2014), Sort i kachestvo pererabotannoj produkcii iz tomatov, Selekcija, semenovodstvo i tehnologii vyrashhivanija ovoshhny, bahchevyh, tehnicheskih i kormovyh kul'tur, (1), pp. 150-156.

Milliatti M. C., LANNES S. C. D. S. (2018), Impact of stabilizers on the rheological properties of ice creams, Food science and Technology, 38, pp. 733-739, DOI: 10.1590/fst.31818.

Müller-Maatsch J., Bencivenni M., Caligiani A., et al. (2016), Pectin content and composition from different food waste streams, Food Chemistry, 201, pp. 37-45, DOI: 10.1016/j.foodchem.2016.01.012.

Pavlyuk R., Pogarska V., Pavlyuk V., et al. (2018), The development of new method of production of healthy ice-cream-sorbet of fruits and vegetables with a record bas content, EUREKA: Life Sciences, (6), pp. 33-40, DOI: https://doi.org/10.21303/25045695.2018.00805.

Pavlyuk R., Pogarskaya V., Pogarskiy A., et al. (2018), Development of the nanotechnology for wellness products naturesuperfood-fruit and vegetable ice-cream sorbets 
with a record content of biologically active substances, Vostochno-Evropejskij zhurnal peredovyh tehnologij, 6(11), pp. 59-68, DOI: 10.15587/1729-4061.2018.148071.

Podkorytova A. V., Kadnikova I. A. (2009), Kachestvo, bezopasnost' i metody analiza produktov iz gidrobiontov, Rukovodstvo po sovremennym metodam issledovanij morskih vodoroslej, trav i produktov ih pererabotki, 3, pp. 81-82.

Polishchuk H. Ye., Matsko L. M., Honcharuk O. V. (2013). Doslidzhennia vplyvu teplovoho obroblennia na strukturuiuchu zdatnist yabluchnoho piure, Nauka ta innovatsii, 9(4), pp. 35-40.

Sagar N. A., Pareek S., Sharma S., et L. (2018), Fruit and vegetable waste: Bioactive compounds, their extraction, and possible utilization, Comprehensive Reviews in Food Science and Food Safety, 17(3), pp. 512-531, DOI: 10.1111/1541-4337.12330.

Syed Q. A., Anwar S., Shukat R., et al. (2018), Effects of different ingredients on texture of ice cream, Journal of Nutritional Health \& Food Engineering, 8(6), pp. 422-435, DOI: 10.15406/jnhfe.2018.08.00305.

Tomovska J., Gjorgievski N., Makarijoski B. (2016), Examination of pH, Titratable Acidity and Antioxidant Activity in Fermented Milk, Journal of materials Science and Engineering, Journal of Materials Science and Engineering A, 6(11), pp. 326-333. DOI: 10.17265/2161-6213/2016.11-12.006.

Torres M., Canet, W. (2001), Rheological properties of frozen vegetable purees. Effect of freeze-thaw cycles and thawing conditions, European Food Research and Technology, 213(1), pp. 30-37, DOI: 10.1007/s002170100314.

Velichko N. A., Mashanov A. I., Bujanova I. V. (2018), Vozmozhnost' ispol'zovanija kapusty brokkoli dlja obogashhenija mjasnyh rublenyh polufabrikatov, Vestnik Krasnojarskogo gosudarstvennogo agrarnogo universiteta, 3(138), pp. 160-164.

Voragen A. G., Coenen G. J., Verhoef R. P., et al. (2009), Pectin, a versatile polysaccharide present in plant cell walls, Structural Chemistry, 20(2), pp. 263-275, DOI: 10.1007/s11224-009-9442-z.

Yovbak U., Obolkina V., Krapivnitska I. (2013), The use of plant material to create semi-gelatinous pastry products, The second north and east European congress on food, $\mathrm{pp}$. 226.

Zapata A. D., Escobar C. A., Cavalitto S. F., et al. (2009), Evaluación de la capacidad de solubilización de pectina de cáscara de limón usando protopectinasa-se, Vitae, 16(1), pp. 67-74.

Zapata A. D., Hours R. A., Cavalitto S. F. (2017), Protopectinase-se from Geotrichum klebahnii: Studies of the adsorption and pectin-solubilization capacity, Dyna, 84(201), pp. 216-223. 